Archaeological Journal

\title{
Roman Inscriptions Discovered In Britain In 1879
}

\section{W. Thompson Watkin}

To cite this article: W. Thompson Watkin (1880) Roman Inscriptions Discovered In Britain In 1879, Archaeological Journal, 37:1, 136-154, DOI: 10.1080/00665983.1880.10851931

To link to this article: http://dx.doi.org/10.1080/00665983.1880.10851931

曲冓 Published online: 14 Jul 2014.

6 Submit your article to this journal

Q View related articles $₫$ 


\section{ROMAN INSCRIPTIONS DISCOVERED IN BRITAIN IN 1879.}

By W. THOMPSON WATKIN.

During the year a fair average number of inscriptions have been found in various parts of the kingdom, a few of them being of great interest.

I will commence with Bath, where, in February, a portion of a sepulchral stone was found in York Street, during some improvements for the drainage of the mineral water springs, near the ancient Roman baths. It was built up into a wall. The letters remaining were-

$$
\begin{gathered}
\text { Q. POMPEIVS } \\
\text { ANICETVS } \\
* * *
\end{gathered}
$$

There are some portions of letters remaining at the commencement of the third line, which look like crI, but they are too much worn and shattered to be pronounced upon definitely. I am indebted to the Rev. H. M. Scarth for a copy of the inscription.

At Caerleon, a portion of an inscription recently found (though not last year) and preserved in the museum there, was sent to me by Professor J. O. Westwood, asking for a reading. The extant portion was-

\section{*SDEMEX \\ VOTOPO}

VSVIT

My reading of this was (eiu) sdem ex voto posuit, which is adopted by Professor Westwood in the Lapidarium Wallicie. It is on the broken base of an altar.

Early in the year I was favoured by Mr. A. D. Berrington of Pant-y-Goitre, Abergavenny, with a rubbing of an inscribed stone found in "restoring" the church of Llanbadarn Fawr, in Radnorshire. It was necessary, during these operations, to take the walls of the church down and dig at least three feet below the original 
foundation. It was then found that a number of dressed stones and lumps of concrete were built into the walls, especially at the west end. Among them was a stone fifteen inches in length by five-and-a-half inches wide, inscribed-

\section{$>$ VAL. FLAVINI}

i.e. Centuria (Val)erii Flavini-"The century of Valerius Flavinus." The letters are elegantly cut, and undoubtedly of the style of the Higher Empire. There is every reason to believe that the stone came from the Roman castrum at Castell Collen, on the banks of the Ithon, within two miles distant. It is of the class termed by Professor Hubner, tabellae ansatae, and is the first Roman inscription recorded to have been found in Radnorshire. It was found in 1878, and is now built up into the inside wall of the church porch.

I am also indebted to Mr. Berrington for a copy of the inscription found on a stone at Goldcliff, near the mouth of the Usk-which is now in the possession of $\mathrm{Mr}$. Octavius Morgan, at his seat "The Friars." It is a slab of lias limestone, the material of which the cliff above the spot where it was found is composed, and was found in November, 1878, projecting from the wharf (or grassy land outside the sea-wall) "near the point of the proper left of the mouth of Goldcliff Pill," at a spot where several feet had been carried away by the tide. It was lying at some little depth in the soil, and bones were near it. The inscription is -

$$
\begin{aligned}
& \mathrm{COH} \text {. I } \\
& \text { o. STATORI } \\
& \text { II } I \mathrm{M}
\end{aligned}
$$

The reading of this seems to be Coh(ortis) I centuria Stator(ii), but the last line as it stands seems inexplicable. The stone was found in ground belonging to Eton College, by the provost of which, Mr. Morgan was allowed to retain it, and he intends to deposit it in the Caerleon Musetum.

In my list of inscriptions for 1878, I referred (Journal, vol. xxxvi, pp. 165-6) to the inscription No. 150 in Dr. Hübner's list (Corpus Inscr. Latin. vol. vii), which was found at Llanio, Cardiganshire. The reading of it, given by Sir R. C. Hoare, was COH . II . A . . . FVP, and that by 
Sir S. R. Meyrick (Cardiganshire, pl. 5, fig. 9), which I did not at the time quote, was -

\section{COH II-A ' TVR}

I expressed the decided opinion, based upon a drawing received from Professor Westwood, showing the upper part of the letters ST after COH . II .A that COH II ASTVRVM was intended. This is not only confirmed by the appearance of the letters TVR in Sir S. R. Meyrick's plate, but also by the recent discovery of a stone built into the south wall of the tower of Llandewi Brevi church, about a mile distant, which is said by Professor Westwood to have borne the inscription-

\section{MIBVS \\ I. AST}

Of course this is a mere fragment, but from the engraving of the stone given in the Lapidarium Wallice, I take the first letters remaining to be $\mathrm{AN}$ ligulate instead of $\mathrm{M}$, and that the word has been (M)ANIBVs when entire. The stone was nearly circular and was ten inches in diameter, but has unfortunately been removed, and was "sought for in vain during the Lampeter Meeting" of the Cambrian Archæological Association in 1878. That COH II . AST has been in the second line seems certain. This is the second instance of the presence of auxiliary forces in South Wales, the other being that of the Ala Hispanorum Vetionum, named in my last list.

At York, during the past year, there was found a fragment of an inscribed stone tablet bearing the letters -

\section{TRAIANV}

AVG . P

It is evidently part of an inscription, containing either the titles of Trajan or of his successor Hadrian (Trajanus Hadrianus).

A second stone found in the same city is described by the Rev. Canon Raine (to whom I am indebted for copies of both this and the previous inscription) as "a label with a double front, under a large head, which has stood originally, it is thought, at the corner of some large tomb." On it are the letters

DM I CE

The letters DM evidently stand for Diis Manibus. 
An interesting discovery also occurred at Lincoln in April during the progress of the new drainage works. It was that of a Roman milestone, found standing apparently in situ, at the intersection of the four great streets of the Roman city, its exact centre. The form of the stone is that of a square pillar, with chamfered angles seven feet four inches high and one foot four inches wide. The inscription upon it, which is rudely and not deeply carved, runs thus-.

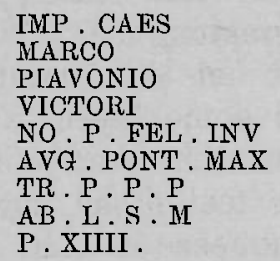

Several of the letters are ligulate, but in the above copy I have untied them. The expansion is plainlyImp(eratori) Caes(ari) Marco Piavonio Victorino P(io) Fel(ici) Inv(icto) Aug(usto) Pont(ifici) Max(imo) Tr(ibunitia) $\mathrm{p}$ (otestate) $\mathrm{p}$ (atri) $\mathrm{p}$ (atriae). $\mathrm{Ab} \mathrm{L}$ (indo) $\mathrm{S}$ (egeloco) $\mathrm{m}$ (ilia) $\mathrm{p}$ (assuum) xiiil. The only other stone found in Britain bearing the name of this emperor, who reigned A.D. 267-8, was found at Neath, in Glamorganshire, and is now preserved at Swansea. It is also a milestone. In the fifth Iter of Antoninus, Segelocum is stated to be fourteen Roman miles from Lincoln, and between that city and Doncaster. ${ }^{1}$

I am also indebted to Mr. A. D. Berrington for a copy of an inscription (fragmentary) upon a portion of a tile found at the Roman villa at Bignor (Sussex), and now preserved there. It is

\section{J JRSVE $\sim$}

and the letters are about four inches high, the s being within an 0 .

At Escombe, near Binchester (co. Durham), Dr. Hooppell informs me that there has been found built up into the wall of the old church there (of Saxon date) a stone inscribed-

i.e. Leg(ionis) Sextae.

LEG . VI,

1 See Joưnal, xxxvi, 281, 
At Binchester itself, during some excavations, two inscriptions were found. The first occurs on a votive tablet of grit stone, much broken on the proper right. In its present state it is twenty-three inches in height, sixteen inches wide at the top, and ten inches wide at the bottom. It would appear to have been originally about eighteen inches wide, and its thickness is about six and a-half inches. On it were sculptured figures of Aesculapius and Salus; the former, larger than the latter, is grasping the left hand of the latter with his right hand; his left hand is on the neck of a serpent coiled round some object. The first portion of the inscription is over the head of Salus, and the remainder beneath the feet of the figures. Dr. Hooppell kindly sent me a squeeze of the inscription, sending another at the same time to Dr. Huibner, and as in the case of the "Regina" monument at South Shields, our readings were identical. The portion of the inscription remaining was -

$$
\begin{aligned}
& \frac{\ldots \text { VLAPIO }}{\ldots \text { SALVTE }} \\
& \text {...... C.R.M.AVRE } \\
& \text {..... OCOMAS . HE } \\
& \text {.......L. M. }
\end{aligned}
$$

The reading of this is-(Aesc)ulapio (et) Saluti (pro salu)te Alae Vet(tonum) c.R.M. Aure(lius) .... ocomas $\mathrm{Me}$ (dicus) . V.S.L.M.

Though recognising "... ocomas" as a portion of the cognomen of the dedicator, I would not suggest the probable name. Dr. Hooppell suggested GLOssocomas, a friend of his suggested CHRYsocomas, whilst Professor Hubner considered that HABRocomas was the correct name. The latter is probably the real cognomen of the dedicator. My friend, Mr. H. C. Coote, F.S.A., gives this opinion also.' The letters $\mathbf{C} . \mathbf{R}$. in the inscription stand of course for $C$ (ivium) $R$ (omanorum). The $v$ and $\mathrm{E}$ in VET are ligulate, whilst the usual formula, $V$ (otum) $S$ (olvit) $L$ (ibens) $M$ (erito) is the expansion of the last four letters.

The only other example in Britain, of a dedication to

\footnotetext{
$1 \mathrm{Mr}$. Coote remarks "Habrocomas" is no doubt the cognomen; being a medicus, he bad been a slave, and that name is
}

common enough for men of that station. The Rev. H. M. Scarth suggests $C_{r} r s s o$ comas. 
Aesculapius and Salus, occurs upon an altar found at Chester in the last century, and now preserved in the British Museum. Salus appears separately upon an altar found at Caerleon (and now preserved there), but with the additional title of "Regina;" whilst the only other Latin. inscription to Aesculapius occurs at Lanchester (the next station to Binchester). It is repeated in Greek on the back of the altar. Another inscription to Aesculapius, but in Greek only, was found at the station at Maryport (Axelodunum), and is now preserved at Nether Hall.

The only inscription certainly found in Britain, which names a medicus, was discovered at Housesteads (Bor'covicus) on the Roman wall. Another inscription naming a medicus is preserved in the museum of the Society of Antiquaries of Scotland at Edinburgh, but it is doubtful whether it was found in Britain.

It was not previously known that the Ala Vettonum (a Spanish cavalry regiment) had been quartered at Binchester. As I have pointed out in my paper on the "Roman Forces in Britain," it was in this country in A.D. 104, as we know from the Malpas tabula of Trajan, and inscriptions by it have been found at Bath, near the Grer at Brecon, and at Bowes, the latter being of the time of Severus.

The second inscription found at Binchester occurred upon a flue tile, which was stamped

MPP.

I consider this to be simply the stamp of the maker, perhaps $M$ (anu) $P$ (ublii) P(etronii), but Dr. Hooppell and others have proposed different readings.

In vols. xxxiii, p. 250, and $\mathrm{xxxv}, \mathrm{p} .72$ of the Journal, I have given particulars of a fragment of a Tabula Honestae Missionis found at Walcot, near Bath. in 1815. Mr. Lysons' drawing of it, of which I obtained a copy, is also engraved in the Journal, vol, xxxiv, p. 318. During the present year I was favored by Mr. C. Roach Smith with a rubbing of the fragment, which he had received from the late Mr. Fox, surgeon, of Huntingdon. It appears that the fragment came into Mr. Fox's possession, and with a large collection of other interesting objects, was purchased at his death by the Literary and Scientific Society of Huntingdon, in whose Museum it now is. I am indebted YOI. XXXVII, 
to Mr. Gilkes, the Hon. Sec. of the Institution, for another rubbing of it. After considerable correspondence on the subject and a minute inspection of the fragment by several antiquaries, it seems certain that the first line of the side given first in the plate in the Journal, instead of being IIA should be ETI.A, and thus stand probably for either Cohors I Asturum or Cohors I Alpinorum. In the second and next line, instead of ET . III A, as I have given it from Lysons, in Mr. C. Roach Smith's rubbing (taken some years ago), the letters are ETXII, with what looks like part of an s following, but the Huntingdon antiquaries give as their opinion that the letters now seem to be ETIIIP, so that it is uncertain what cohort is named. I am inclined to think that it may have been ET . $\mathrm{X}$. HISP.

On the other side of the plate, where, following Lysons, I have given III ARTIDIo, both Mr. Smith's and Mr. Gilke's rubbing's, and also the opinion of the Huntingdon antiquaries coincide in giving THARTIDIO.

But the great value of the inscription consisted in its giving us, what from the word PRocvlEIAN, followed by the words CVI P(RAEsT), was considered to be the Alc Proculeiana, a cavalry regiment, previously unknown in the Britanno Roman army list. That this hypothesis was correct, the next discovery that I record will prove.

In the month of June Mr. John Clayton commenced excavating the southern gateway of the station of Cilurnum, upon the wall of Hadrian, of which he is the owner. Many interesting remains were found of the gateway itself, but amongst the debris of the eastern guard chamber, and four feet above the level of the original floor, there were found the remains of two Tabulae IIonestae Missionis. Of one, the greatest part remained, of the other, merely a fragment. The portion of the former which remains is in two fragments, one of considerable extent, the other only a small one. Like all the other tabulae, these fragments have the inscription on both sides of the plate, the repetition of the inscription on one side being at right angles to that on the other side. By these means much of what is missing on one side is restored from the other. The inscription on the nearly perfect tabula is as follows:- 
INSIDE.

imp caes diri HADriani $f$ diri trajani part $n$ divi nerrœ proN $\mathrm{T}$ Aelivs hadrianes anTOninzs arg PIVS pont max tr pot viiii

$\operatorname{IM} p$ ii $\operatorname{COS}$ II $i i p p$

EQ ET PED qui mil in al iii et cole xi $q$ a arg

GAL PROC ET I ....... et $i$ hisp aster et $i$

CELT ET I HISP ET $i$ ael deceor et $i$ ael classica

ET I FID ET II GALL et ii et vi nervior et iii

BRAC ET IIII LING et iiii gallor et sint in

BRITTAN SVB PAPIRio aeliano quinque et vig stip

EMERIT M HON MIssione quorvm nomina subscripta

SVNT C R QVI EORVm non haberent dedit et

CONVB CVM VXORIB 2 s gras trnc halrissent

CVM EST CIV IIS Datc demtaxat singrli

OUTSIDE.

imp cAESAR DIVI HADRIANI F DIVI

trajani PART NEPOS DIVI NERVAE PRO

nop $t$ aeLIVS HADRIANVS ANTONINVS

aig pirs PONT MAX TR POT VIIII IMP II COS IIII

$p$ p eqvit et $p$ EDIT QVI MILITAVER IN ALIS III

et collort XI $q v$ AE APPELL AVG GALL PROCVL ET I

$\ldots \ldots \ldots$ ET I HISP ASTVR ET I CELTIB

et $i$ hisp et $i$ AELIA DACOR ET I AELIA

CLASSICa et $i$ fid $v$ ARD ET II GALLOR ET II ET

VI NERVIor et iii braC ET IIII LING ET IIII GALL

ET SVNT IN BrtlaNNIA SVB PAPIRIO AELI

ANO QVINQre et rigiNTI STIPEND EMERIT

The capital letters shew those that are in existence on the fragments, those in small type are supplied as far as the names of the corps are concerned from the opposite side, whilst some of the formulae are supplied from other examples.

The tabula is of the reign of Antoninus Pius, and the words TR . POT . VIIII . IMP. II . COS. IIII prove it to be of the date A.D. 146. It is in favor of three alae and eleven cohorts. The name of one of the alce is lost; of the others, the abbreviations used are AVG. GALL . PROCVL and I . FISP. AsTVR. The latter is well known from the Riveling tabula, and from the Notitia, being mentioned in the latter, as stationed at Benwell (Condercum), on the wall of Hadrian, where they have left a number of inscriptions. The other ala appears to be that named in the Walcot fragment. We now learn that it bore the prefix of Augustc, and was composed of Frenchmen, or rather was of Gallic origin. It doubtless derived its title of Proculeiana from the officer who first raised or commanded it. The whole of the eleven cohorts named are well known to have been in Britain. Seven of them occur 


\section{ROMAN INSCRIPTIONS DISCOVERED IN BRITAIN.}

in the other tabulae, but the Cohors Aelia Classica was previously known from the Notitia only, whilst the Cohors I. Aelice Dacorum and Cohors IIII Gallorum were known from the Notitia, and the inscriptions they have left, but occur in none of the previously discovered tabulae. The Cohor's II. Gallorum was previously only known by the inscriptions which it has left at Old Penrith.

Another interesting fact which we gather from the tabula is the name of a new Imperial Legate or Governor of Britain, Papirius Elianus. Whether this legate was the immediate successor of Lollius Urbicus, who we know was in Britain between A.D. 138-144, is a matter of uncertainty. Nothing else is known of him.

The portion of the other tabula found at the same time, contains on one side merely a few words of the opening formula, and on the other a few letters of the closing formulcie. They are-

$\begin{aligned} \text { VITRAIANIPAR } & \text { HO } \\ \text { TAELIVS } & \text { ROM } \\ \text { IFMAX } & \text { VXQV } \\ \ldots . . . & \text { EVIC }\end{aligned}$

It appears to be also of the reign of Antoninus Pius, and on the reverse the abbreviations are more condensed than in the other tabula. For instance the letters vx. Qv. I take to indicate vXORIBUs QUAS, whilst the letters underneath them are very puzzling; the first one in the line instead of being $\mathbf{E}$ may probably be a rude cr ligulate.'

During the same excavations there was found, built into the wall of the eastern guard-chamber of the gateway, a stone bearing the inscription-

$$
\text { LEG . VI . VI . }
$$

The letters were not very deeply cut, and were not of the fine character of the inscriptions of the higher empire.

In his recent excavations at the castrum at Irchester, the Rev. R. S. Baker found a piece of wall plaster with portions of a few letters, of what appears to have been a Greek inscription, but nothing satisfactory can be made out.

There is at present preserved at Easton Grey, near Malmesbury, by Graham Smith, Esq., a Roman inscribed

1 Mr. Clayton, to whom I atn indebted for a photograph of these tebulac, informs me that their ultimate destination is the British Museum. 
and sculptured stone, which is said to have come from a Roman station in the neighbourhood called "White Walls." The sculpture consists of four standing figures, in a recess flanked by short columns, and surmounted by a pediment. On the latter appear the letters

$$
\text { CIVILISIISTT }
$$

After the first $\mathrm{s}$ all the letters except the second $\mathrm{s}$ are indistinct. The $\mathrm{L}$ in the inscription has a very rustic character, and looks like a reversed s, but the other letters are fairly well cut.

I am indebted to the Rev. Dr. Raven of Yarmouth for a sketch of this stone, taken some time since. Without further information I cannot hazard an opinion upon its nature. I have been inclined to read the inscription as CIVILISETSVIS, but only conjecturally venture upon this reading. Dr. Raven writes to me concerning the stone-"The subject seems without question to be the submission of the burbarian chief Civilis, who has his hands fixed in front of him, apparently in some kind of frame. Of the other figures, the leader bears a scroll, the second (probably) the centurion's virga, the third a scourge of some kind (?)"'2

A tew weeks ago, a small portion of the MSS. of the Rev. John Watson, M.A., F.s.A., rector of Stockport, and a well-known antiquary of the last century, were sold by auction in Manchester. In one of the volumes was an account of a journey to Bath in 1776, at the end of which was a list of Roman inscriptions found in Bath, with which the writer was acquainted. He names $\mathrm{Dr}$. Hubner's Nos. 36, 37, 43 and 46, and another one inedited and thus described-

"The following was dug up about the year 1776 out of the foundation of Westgate House in Bath. The stone was two feet three inches long and one foot three inches wide. Uncertain where lodg'd."

$$
\begin{gathered}
\text { A. ESVOV } \\
\text { Es CAN } \\
\text { I EN } \\
\text { DN }
\end{gathered}
$$

1 It is engraved by Sir R. H. Hoare in his "Ancient Wilts." Roman Era, p. 100 .

2 This sculyture scems of a much later period. Can it refer to the Governor of Britain of the name of Civilis sent over in A.D. $36 \%$. 
It is evidently wrongly copied. Is it a dedication to Aesculapius? I am indebted to my friend $\mathrm{Mr}$. J. P. Earwaker, F.s.A., for this information.

$\mathrm{Mr}$. Robert Blair has lately brought into notice two leaden seals preserved in the Newcastle-on-Tyne Museum, and which originally came from the station of Bremenium (High Rochester). They are of the same class as those found at Brough (Verterae) and at South Shields. They bear the following rude inscriptions-

(1)

Obv. MV Rev. CFI
$(2)$

Obv. ${ }^{\mathrm{PH}} \quad$ Rev. IID or IVV

The year has been rich in re-discoveries.

It had for some time been generally thought that the milestone bearing the name of the Emperor Numerianus, found near Kenchester (Dr. Hübner's, No. 1165) about the year 1800 had been lost, but I am glad to say that it has again come to light. The credit of its re-discovery belongs to the Rev. H. Cooper Key, rector of Stretton, who, at the request of $\mathrm{Mr}$. A. D. Berrington, enquired into the matter. As its full history is now known it may be as well to make the same public. The stone, which in its present state is about twenty-four inches high by eighteen wide, has the bottom broken off and the upper part damaged. It is about five inches thick, rough at the back, and formed of the coarse sandstone of the country. It was found at Old Weir, about a mile from Kenchester, in the yard of the farm-house at the former place by the Rev. Chas. J. Bird, F.s.A., rector of Mordiford. By him it was removed to Mordiford Rectory. He died about 1848 at a great age, and all his collections were dispersed except this stone, which was retained at Yarkhill by his son, the resident clergyman. At his death there was another sale, when the stone was purchased for five shillings by the Rev. Mr. Brown, rector of Dormington, who had married Mr. Bird's daughter. At Dormington it is still preserved, and was minutely inspected by $\mathrm{Mr}$. Berrington in October last, and a squeeze taken of it by the same gentleman. The fifth line has been the only doubtful one since the inscription was first known. Before starting to see it $\mathrm{Mr}$. Berrington asked me what to look for in this line. I 
replied that I imagined that the letters represented part of the name of the neighbouring station of Ariconium, probably ARICo instead of . RP . C. D as previously given. $\mathrm{Mr}$. Berrington confirmed partially my reading. $\mathrm{He}$ makes the line to read /. RIC . LII. This seems to mark the distance from VRICONIVM (Wroxeter), which is given in the Itinerary of Antoninus as fifty-one miles from Magna (Kenchester), and the remaining mile from Kenchester to Old Weir would make the agreement between the stone and the Itinerary exact. It is also noticeable that the name of Numerianus is spelt as Numorianus, the whole inscription being-

$$
\begin{aligned}
& \text { IMP . C } \\
& \text { MAR . AVR } \\
& \text { NVMORIAN } \\
& \text { O } \\
& \text { /RIC . LII }
\end{aligned}
$$

The first letter $\nabla$ in the fifth line has been nearly altogether lost through damage to the corner of the stone, but the second stroke of the letter is partly visible. There appears never to have been more than the letter o in the fourth line.

In my list of inscriptions for 1877 (Archaological Joumal, vol. xxxv, p. 68), I briefiy described a Roman altar found at Hereford. It was formerly preserved at the old Hereford Museum, on the Castle Green, but had been lost sight of for some years, having been concealed by ivy and other creeping plants, on the exterior of the building. It has lately, owing to the exertions of $\mathrm{Mr}$. J. T. Owen Fowler, been re-discovered and removed to the Hereford Free Public Library and Museum, now standing on the staircase of that building. From the Committee Minutes of the Hereford Permanent Library, it has been found that after the meeting of 4 th June, 1822, the following entry was made:-

"The Roman altar was discovered in 1821, when the foundations of the Subscription Billiard Room, adjoining the Hereford Permanent Library were being dug, and it was placed by $\mathrm{Mr}$. John Allen, junr., in the open space belonging to the library as a curious relic of antiquity. The inscription is almost obliterated, but the word DEO may still be made out." 
Though faint, the same word is still visible - the whole of the lettering which can be made out being-

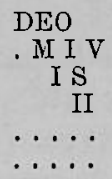

The inscription, appears to have consisted of six lines, and cannot be a dedication to Minerva as previously suggested by Mr. Scarth. The altar is three feet fourand-a-half inches in height, and the letters are elegantly carved.

The third re-discovered inscription was that found at Bowness (Dr. Hübner's No. 952) on which a communication appeared from me in vol. xxxvi, pp. 422-4 of the Journal. Its correct reading, as finally established by Dr. McCaul, is-

$$
\begin{aligned}
& \text { SED DATE VT FETVRA QAESTVS } \\
& \text { SVPPLEAT VOTIS FIDEM } \\
& \text { AVREIS SACRABO CARMEN } \\
& \text { MOX VIRITIN LII'TERIS. }
\end{aligned}
$$

I sugrosted the following collocation :- "Sed date fidem ut foetura suppleat quaestus votis," the meaning being"But (ye gods) give us your assurance that the production (of the animal dedicated) shall crown our vows with gains."

"Aureis sacrabo mox viritim litteris."

"I (the dedicatur) will commemorate the vow in golden letters."

I also pointed out, in the above named article, that the inscription was in Trochaic Septenarian verse-the name of the dedicator I take to be some such name as Vettonianus - but Mr. W. T. Arnold, author of "Roman Provincial Administration," writes to me that "Nonianus seems to be clearly preferable to Vettonianus, both from the size of the stone, and also more particularly because 'Nonianus dedico' is just the rhythm we want in that particular line, the verses being, as they are, cut into halves throughout. In fact, I would suggest that the neatness with which the man's name, and the verb of dedication fitted into the metre, was the original cause which suggested a metrical inscription." 
The stone is now in the Carlisle Museum.

The fourth re-discovered stone (Dr. Hübner's No. 417) has been found built up in the barn of a farm-house at Newtown, near Old Mawbray, Cumberland. The reading given in Hutchinson's "Cumberland" of the inscription is

L . TA PRAEF . COH , II PANNON . FECIT

but the three first letters appear to be LIA, the stop after the $\mathrm{L}$ being apparently an accidental mark-as it is below the level of the other stops in the line. At present the second letter resembles an $\mathrm{I}$, if it has been a $\mathrm{T}$ the upper part has gone. But the most peculiar fact is, that the inscription is on two stones built up in a line with each other-the $\mathrm{R}$ in PRAEF being the commencement of the inscription on the second. There is room on the first stone for other letters before LIA, but they appear to have never existed. The letters on both stones are of the same size and character, so that the inscription now stands as

\section{LIA . P I RAEF . COH . II . PANNON . FECIT .}

The stone has been purchased for Mr. Senhouse, to be deposited with his collection at Nether Hall, Maryport. It has no doubt, as Hutchinson stated, been obtained from the Roman castrum at Beckfoot, which has recently, through the zeal of Mr. Joseph Robinson, been partially laid bare. I am indebted for the above information to Mr. R. S. Ferguson, F.S.A.

In February, there was found in Tottenham Court Road, London, during some excavations, a marble tablet with a figure of a gladiator in relief, inscribed -

$$
\begin{aligned}
& \therefore \text { NIA MAPTIAA } \\
& \triangle \mathrm{H} . \mathrm{T} \Omega \text {. AN } \triangle \mathrm{PI}
\end{aligned}
$$

This stone which is engraved in vol. xi of the Archoeologia, p. 48, and given by Dr. Hübner at p. 21 of his vol. vii of the Corpus Inscriptionum Latinarum, had been lost for upwards of a century, being first noticed among the ruins of a house in Islington. I have no doubt that it originally was brought over as a curiosity from the continent, and is not a Britanno Roman inscription at all.

I have again to add a few previously discovered inscriptions which Dr. Hübner has overlooked in his work. In the list of stones found at the castrum at Tomen $y$ Mur, Merionethshire, these three inscriptions are omitted. YOL, XXXVII. 


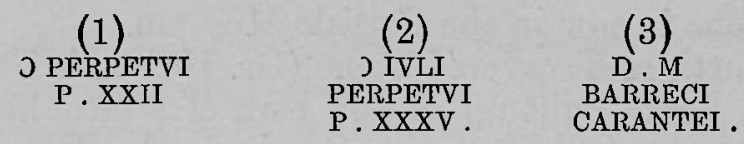

The two first are built up, with Dr. Hübner's Nos. 144 and $1339 a$, in the terrace wall of Tan-y-bwlch Hall, near Festiniog. All four of the stones are twelve inches by ten, and are engraved by Professor Westwood in plate 74 of the Lapidarium Walliae.

The third of these, which is fig. 4, pl. 78, in Professor Westwood's work (though no letter press description of it appears to be given), is undoubtedly of the Roman period, and evidently reads $D(i i s) \quad M$ (anibus) Barreci Carantei, the TE in CARANTEI being ligulate. The names would seem to be British, Latinised.

At Cirencester there have been for many years in the museum, two Roman tiles found with others in that town and inscribed in very large and fine letters

$$
\text { I. H.S. }
$$

but Dr. Hübner omits them.

Of the three Roman altars found at Adel, near Leeds, and preserved in the vestry of the church there, two are inscribed, though Dr. Hübner only gives the one dedicated to Brigantia. The other is inscribed

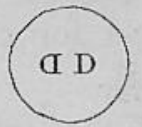

Standing by themselves simply, it is difficult to interpret the meaning of these letters, unless Diis Deabus be what is meant.

On a Roman cup found at Chichester, and now preserved in the museum at that city, there is scratched

LVPO. $\mathrm{X}$.

In my last annual list of inscriptions (Archoological Journal, vol. xxxvi, p. 166) I noticed a small fragment found at Segontium (Caernarvon), bearing the letters SE. It is engraved by Professor Westwood (fig. 6, pl. 81) in the Lapidarium Walliae, where he says the letters are three-and-one-third inches in height, but he also engraves (fig. 5, pl. 81) another fragment found at the same place, bearing in letters nearly four inches high, the letters

A. $M$. 
which seems to have formed part of one of the upper lines of the same inscription. The latter, from the size and elegant carving of the letters, must have been a fine one.

In vol. xxxv of the Journal, p. 290, I have given, but erroneously, the name of $Q$. ATTINVS as occurring on "Samian" ware found at Herringfleet, in Suffolk. It turns out however, that the inscription is on a bronze vessel, and reads

\section{QVATTENVS . F .}

(Vide Proc. Suffolk Archceological Institute, vol. iii, p. 406, and compare with Journal of British Archaoological Assuciation, vol. xxxv, p. 438).

Two other inscriptions, which have remained inedited, and probably, in one case at least, will remain so, have to be noticed. The first was found at Lowgill, on the line of the Roman road between Ribchester and Overborough, under the pavement of the road, and about the year 1824 was in the possession of Mr. Court, of Lowgill (Rauthmell's Overborough, second edition, 1824, Appendix No. ii, p. 134). I am making enquiries as to whether it is still in existence.

Of the second, Professor Westwood, at p. 183 of the Lapidarium Wallia, says - "In the roof of one of the chambers of Caernarvon Castle, on the south side and towards the eastern end of the castle, is a stone, which appears to bear an inscription, pointed out by Sir Llewellyn Turner during the meeting of the Association in 1877, but of which I have not been able to obtain a drawing."

In vol. xxxiii, p. 259 of the Journal, I gave a copy of an inedited fragment of a tombstone found at Ellenborough (Maryport). I there stated that the praenomen of the deceased was Flius. I should have said that Alius was the nomen, and the whole I would read Diis Manibus Sacrum Acl(ii) (Acili)ani.

I have a word to add with regard to one of the inscriptions given by Dr. Hubner, No. 153. From a copy of this, preserved in the Lansdowne MS., 825-84, in the Bodleian Library, which agrees more with the copy given in Jones' History of Brecknockshire than with that in the Gentleman's Magazine (both of which Dr. Hubner gives), I would read the first line of the first part (DIIS . M)ANIBVS, the second I would read VAL . ARMIIGER ... 
(we have an Aurelius Armiger named in an inscription found near Walton Castlesteads, Cumberland) ; the third line is uncertain. In the second division of the inscription I think we have in the second line PIENTIS in a ligulate form, and the third line I take to be FII. FEC.

In the centurial inscription found at Manchester, of which I treated in vol. xxxiv, pp. 141-2 of the Journal, there is, as I then said, "a figure which seems like a note of interrogation reversed," preceding the $\mathrm{P}$ in the last line. I have since noticed that this resembles one half of the figure $(\Omega)$ which occurs in a centurial inscription (Dr. Hubner's, No. 172) found at Chester. The last-named figure, Dr. McCaul (Brit. Rom. Insc., p. 119) considers as indicating the direction of the limes, "either from east to west or v. v.," and I think he is right. In that case the figure on the Manchester stone indicates something similar.

Dr. Hubner's No. 1307, which for a long time had been lost sight of, is, it seems now, in the possession of $\mathrm{Mr}$. Robert Fitch, F.S.A., of Norwich, a well-known antiquary.

P.S. - An altar was also found at Binchester during the past year about fifteen inches high, inscribed

\section{MATR \\ TRAMAR \\ EQVITAL \\ VETTCR \\ VSLM .}

i.e., Matr(ibus) Tramar(inis) Equit(es) Al(ae) Vetto(num) $C$ (ivium) $R$ (omanorum) V(otum) S(olverunt) L(ibentes) $M$ (eritis); the translation being "To the Transmarine Mothers, the Cavalry of the Ala Vetonum, Roman Citizens, perform their vow willingly to deserving objects." The inscription is much worn, and for a long time was not detected. Both it, and the one mentioned previously, dedicated to Aesculapius and Salus, are preserved in the museum of the University of Durham.

I am indebted to the Rev. R. E. Hooppell, LL.D., for the copy of another inscription found in October, 1879, during some sewerage works at Chester le Street. It is the right hand portion of a large tablet about (probably) one fifth of the whole, the terminations of the lines being all that remains. It runs thus 


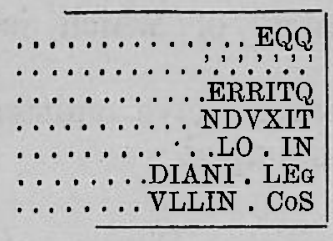

The last line is complete enough to give us the date of the inscription ; it would commence with the abbreviation $A V G$. PR . PR following the name of the legate in the previous line. The remainder would be SABIN. $\overline{\mathrm{II}}$. ET ANVLLIN . Cos . and proves that the stone was erected in the year A.D. 216 when "Sabinus for the second time and Anullinus" were Consuls. From the first line it is probable that either a praefect of horse (PRAEF . EQQ) or the soldiers (equites) of a cavalry regiment raised the stone. The portion of the second line, which ought to have been left, has been, as in many other cases, purposely erased, as it contained the epithet Antoniniana which the regiment had assumed from the reigning emperor (Caracalla). The erasure, however, I opine took place some years afterwards, when Elagabulus was murdered, and the epithet which had been assumed by many regiments in compliment to him also was obliterated on account of his unpopularity. The third line is a puzzle ; unless there has been an error of the mason, ERJTQ(VE) would have been easier to understand. In the fourth line, we have I think "conduxit," as there seems to be part of the 0 attached in a ligulate form to the first stroke of the $N$. The fifth line is doubtful ; it may have been (A. So)Lo. IN (struxit) or IN (stante), but in the face of conduxit in the previous line it is difficult to give the true reading. The next line is plainly ... DIANT . LEG . the AN being ligulate, and has contained the name of the imperial legate in the genitive. His cognomen has been some such name as Secundianus, Aufidianus, or Gordianus.

There was also found in the autumn of 1879 , amongst the ruins of a Roman building at Titsey, Surrey, a walling tile inscribed- 
154 ROMAN INSCRIPTIONS DISCOVERED IN BRITAIN.

the probable expansion of which is APENDINI, as a cognomen.

Dr. Hubner appears to have omitted from his list of "Tegulae" the tiles stamped

$$
\text { LCC }
$$

found in the Roman villa at Bignor. (Vide Gent. Mag., Aug. 1818, p. 175.) 